\title{
An integrated approach for assessing translocation as an effective conservation tool for Hawaiian monk seals
}

\author{
Tenaya A. Norris ${ }^{1,2, *}$, Charles L. Littnan ${ }^{3}$, Frances M. D. Gulland ${ }^{1}$, Jason D. Baker ${ }^{3}$, \\ James T. Harvey ${ }^{2}$ \\ ${ }^{1}$ The Marine Mammal Center, Sausalito, California 94965, USA \\ ${ }^{2}$ Moss Landing Marine Laboratories, Moss Landing, California 95039, USA \\ ${ }^{3}$ Pacific Islands Fisheries Science Center, NOAA, National Marine Fisheries Service, Honolulu, Hawaii 96818, USA
}

\begin{abstract}
For threatened and endangered species, translocations have been widely used to mitigate multiple sources of mortality that threaten population recovery. Although numerous Hawaiian monk seals Neomonachus schauinslandi have been translocated for a variety of purposes, few monk seal translocations have addressed the problem of prey limitation. To assess the efficacy of using translocations to mitigate reduced prey availability, 12 weanling monk seals were translocated with pre-release health screening and post-release monitoring. Specifically, the health, foraging behavior, habitat use, and survival of translocated seals were compared with those of 17 monk seals resident to the release site. There was little evidence of infectious diseases in translocated and resident seals, although Chlamydophila abortus antibodies and enteric bacteria were detected in many individuals. Translocated and resident weanling seals also demonstrated similar diving, movements, and habitat use, whereas resident adult seals had greater variability in foraging patterns. First-year survival for translocated weanlings $(50 \%, \mathrm{n}=12)$ and non-translocated weanlings at the donor $(31 \%, \mathrm{n}=36)$ and recipient sites $(69 \%, \mathrm{n}=16)$ was related to weaning body size, with larger individuals having greater survivorship. These results supported 3 main conclusions that have important consequences for future translocation and population recovery efforts: (1) there was minimal risk of exposing seals to novel infectious diseases as a result of translocation; (2) individuals translocated with limited foraging experience rapidly adapted to their post-release environment; and (3) translocation for the purpose of mitigating prey limitation is a viable and important conservation tool for Hawaiian monk seals.
\end{abstract}

KEY WORDS: Translocation · Post-release monitoring $\cdot$ Health assessment $\cdot$ Foraging conditions · First-year survival $\cdot$ Hawaiian monk seal

\section{INTRODUCTION}

Species conservation has long included the use of direct protection and policy reform to promote population stability and growth. In instances when these traditional management tools have not altered decreasing population trends, applied conservation strategies increasingly are implemented (Fischer \&

\footnotetext{
*Corresponding author: norrist@tmmc.org
}

Lindenmayer 2000, Salafsky et al. 2002). Translocation, or the deliberate movement of wild individuals from one location to another, is one such strategy (IUCN 1998, Seddon et al. 2012). To be designed effectively, translocation programs should include thorough pre-release planning and post-release monitoring, such as conducting health screening, assessing habitat quality at the release location, and

(c) The authors and (outside the USA) the US Government 2017. Open Access under Creative Commons by Attribution Licence. Use, distribution and reproduction are unrestricted. Authors and original publication must be credited. 
tracking animals immediately after release and longterm (Wolf et al. 1996, IUCN 1998, Mathews et al. 2006). Many programs, however, fail to assess one or more of these factors that can influence success, and until recently, few translocation studies implemented robust post-release monitoring or experimental approaches with testable hypotheses (Griffith et al. 1989, Dodd \& Seigel 1991, Wolf et al. 1996, Fischer \& Lindenmayer 2000, Sheean et al. 2012). Translocations have been applied widely, with varying levels of success, to reduce the risk of extinction for a variety of threatened and endangered avian, terrestrial mammal, and reptilian species (e.g. Dodd \& Seigel 1991, Reynolds et al. 2008, Gusset et al. 2009). Conversely, there are few instances in which translocations have been used to promote the population recovery of endangered marine mammals (Swan et al. 2016), with the exception of sea otters Enhydra lutris (Jameson et al. 1982) and Hawaiian monk seals Neomonachus schauinslandi (Baker et al. 2011).

Despite legal protections and decades of conservation efforts, Hawaiian monk seal abundance (currently a minimum of 1300 individuals) has continued to decrease at 6 sites in the Northwestern Hawaiian Islands (NWHI) that compose the majority of the species total population (Harting et al. 2014, Baker et al. 2016, Carretta et al. 2016). Prey limitation, which primarily affects seals < 2 yr old, is the main threat for monk seals in the NWHI (Craig \& Ragen 1999, Baker 2008). Chronic poor juvenile survival related to reduced prey availability has persisted since the late 1980s at one site in particular, French Frigate Shoals (FFS; Craig \& Ragen 1999, Baker \& Thompson 2007). Other sources of mortality for this population include shark predation, intra-specific male seal aggression, marine debris entanglement, and sea-level rise (Antonelis et al. 2006, Baker et al. 2006, BertilssonFriedman 2006). Translocations have been used as an important conservation tool to mitigate some of these sources of mortality, and most monk seal translocations moved pups within FFS to reduce their risk of Galapagos shark Carcharhinus galapagensis predation (Baker et al. 2011). Few monk seal translocations, however, have addressed the problem of prey limitation in the NWHI, although few alternative conservation tools are available to mitigate this ecosystem-level threat (Norris et al. 2011, Baker et al. 2013).

The objective of this study, therefore, was to translocate monk seals from a site with poor juvenile survivorship (FFS) to another site in the NWHI that was expected to offer an improved probability of survival as a result of better foraging conditions. Nihoa
Island $(\mathrm{NIH})$ was selected as the release location because, although population monitoring efforts at this site have been sparse and sporadic, monk seal numbers appeared to be increasing and seals were in better body condition compared with other NWHI sites, indicating food resources may be non-limiting (Baker \& Johanos 2004, Carretta et al. 2016). For this study, multiple factors that can influence the success of a translocation program were examined. Specifically, the health, foraging behavior, habitat use, and survival of translocated and non-translocated (resident) monk seals were compared to assess the efficacy of translocations aimed at improving foraging conditions for young seals. This integrated approach served as a framework for ongoing and future interatoll Hawaiian monk seal translocation efforts and likely has implications for other endangered and threatened species reintroduction programs.

\section{MATERIALS AND METHODS}

\section{Translocations and animal handling}

Twelve weanling monk seals were translocated $450 \mathrm{~km}$ from FFS to NIH on 31 August 2008 and 22 August 2009 via the NOAA research vessel 'Oscar Elton Sette' (Table S1 in the Supplement at www. int-res.com/articles/suppl/n032p103_supp.pdf). Only seals with weaning axillary girths $>90 \mathrm{~cm}$ were selected for translocation because monk seals weaned with lesser girths have extremely poor probabilities of survival across all NWHI (National Marine Fisheries Service [NMFS] unpubl. data). Approximately equal numbers of males and females were translocated to minimize skewing of the sex ratio at the donor and recipient sites (Johanos et al. 2010). Additionally, the number of translocated seals was limited to 6 individuals per year to reduce the potential for negative density-dependent impacts at NIH while maintaining adequate sample sizes for statistical analyses. Seals were held in cages and monitored continuously during transport $(\leq 46.5 \mathrm{~h})$ but did not receive food or medical treatment. At $\mathrm{NIH}$, translocated weanling (TW) seals were released within $100 \mathrm{~m}$ of the single sandy beach because a shorebased release was not physically possible. In addition, 9 resident adult (RA) and 8 resident weanling (RW) monk seals were captured at NIH on 10-11 September 2008 and 1-4 September 2009 (Table S1). All seals were handled for biological sampling, satellite instrument attachment, and morphometric measurements (Baker \& Johanos 2002), except biological 
samples were not collected from RW seals in 2008 due to logistical constraints.

\section{Health data collection and analyses}

Each seal was examined clinically by a veterinarian at the time of handling. Blood and nasal and rectal swabs were collected and stored at $4^{\circ} \mathrm{C}$ for $\leq 6 \mathrm{~h}$ until processed or frozen at $\leq-80^{\circ} \mathrm{C}$ for later processing. To assess the health status of seals before translocation, complete blood counts and partial serum chemistry analyses were performed using manual field techniques (Norris 2013), with results compared to published normal ranges for blood values for this species (Reif et al. 2004). Aliquots of frozen serum were sent to various diagnostic laboratories to test for antibodies to infectious agents, and swabs were used to test for influenza A (2008 and 2009) and B (2008). Fecal samples stored in modified Cary Blair media (C\&S Medium, Medical Chemical Corporation) were maintained at $4{ }^{\circ} \mathrm{C}$ for 6 to $16 \mathrm{~d}$ and cultured for enteric bacteria at University of California, Davis Veterinary Medical Teaching Hospital.

A contingency table was used to test the null hypothesis that there was no difference in pathogen prevalence between resident and translocated seals. The likelihood ratio was used to test statistical significance ( $\alpha<0.05$ for all tests). Only 5 infectious agent categories were included in the analysis (Chlamydophila abortus antibodies, Clostridium perfringens, Escherichia coli, Salmonella spp., and a group of all other enteric bacteria detected in at least 1 seal) to ensure $\leq 20 \%$ of category combinations had expected frequencies <5.0. Post-hoc subdividing contingency tables were used to examine which pathogens likely were responsible if a difference was detected. Statistical analyses were performed using SPSS 20 (IBM Corporation) or MATLAB 7.14 (Mathworks).

\section{Foraging behavior data collection and analyses}

Satellite instrument programming and data processing

A satellite-linked time-depth recorder with a global positioning system (GPS; Mk10-AF tag, Wildlife Computers) was attached to the dorsal pelage of each seal using 10 min epoxy (ITW Devcon). Satellite instruments transmitted 150 to 250 times daily when polar-orbiting NOAA satellites were in view. Transmissions were attempted every $45 \mathrm{~s}$ unless the tag wet/dry sensor was dry for $\geq 10$ min when the transmission interval increased to $90 \mathrm{~s}$. After a tag was dry for $\geq 2 \mathrm{~h}$, transmissions paused. The tags binned dive depth, dive duration, and time-at-depth (TAD) summaries into 14 frequency histograms for four $6 \mathrm{~h}$ periods (start times: 00:00, 06:00, 12:00, and 18:00 h local time). Depth was sampled every $10 \mathrm{~s}$. Dives $<2 \mathrm{~m},<30 \mathrm{~s}$ (2008), and $<60 \mathrm{~s}$ (2009) were not analyzed. Mk10-AF tags also used Fastloc ${ }^{\mathrm{TM}}$ technology (Wildtrack Telemetry Systems Ltd.) to rapidly acquire GPS locations during seal surfacings (Bryant 2007). Fast-GPS fixes were collected at 10 min intervals with a maximum of 4 successful (signal received by $\geq 4$ satellites) and 3 failed attempts per hour. Only Fast-GPS and dive histogram data, transmitted via the Argos Data Collection and Location Service, were used because transmitter recovery was not possible in most cases.

Telemetry data from weanling seals were divided into 2 periods: (1) an initial phase in which weanlings were primarily on land or near NIH and had limited diving activity (post-weaning fast), and (2) a second phase with independent foraging behavior. These 2 phases were used because monk seal pups, similar to other phocids, have large lipid stores and typically fast for prolonged periods after being weaned abruptly (e.g. Reiter et al. 1978, Worthy \& Lavigne 1987). For each weanling seal, the post-weaning fast was defined separately as having ended when the seal first dove $>40 \mathrm{~m}$ deep and moved away from $\mathrm{NIH}$ for $>1 \mathrm{~d}$. Extensive survey effort at FFS allowed post-weaning fast duration and age at translocation to be determined for TW seals using known or estimated birth and weaning dates $( \pm 2 \mathrm{~d})$, excluding 2 unknown birth dates (minimum age was calculated for these animals using date of first sighting). Birth and weaning dates, however, were largely unknown for RW seals because population monitoring efforts at NIH were limited. Adult seals had 1 tracking period, which was synonymous with the independent foraging phase of weanling seals.

Telemetry data for seals with tracking durations $\leq 26 \mathrm{~d}$ of independent foraging or that did not extend beyond the post-weaning fast were excluded from the analyses. All telemetry data processing and analyses were conducted in MATLAB using customwritten and built-in codes. Geospatial data were analyzed and displayed using the Transverse Mercator projection and World Geodetic System 1984 reference ellipsoid in MATLAB's Mapping Toolbox 3.5. For all results, means were reported along with standard error (SE). 


\section{Dive behavior analyses}

The 14 dive depth and duration frequency histograms were condensed into $\leq 6$ bins to reduce the number of bins with zero values and simplify interpretation without losing the resolution necessary to investigate among-group differences in diving activity. For each seal, the proportion of dives per bin was calculated for each depth and duration record to standardize for differences in number of records received. Mean depth, duration, and TAD frequency histograms were compared qualitatively among TW, RW, and RA seals. For weanling seals, dive histogram data were processed and analyzed separately for the 2 tracking periods. Additionally, because a relationship between weaning body size and dive duration has been observed in other marine vertebrates (Watanuki \& Burger 1999, Hindell et al. 2000, Irvine et al. 2000), mean proportion of dives $\leq 6 \mathrm{~min}$, during the foraging phase, was regressed against mass for weanling seals.

\section{Horizontal spatial use analyses}

Fast-GPS locations were filtered to remove inaccurate location estimates $(\leq 2.3 \%$ of locations removed per individual; Freitas et al. 2008, Norris 2013). Filtered locations were interpolated on a $2 \mathrm{~h}$ interval using the hermite spline method (Tremblay et al. 2006). To examine at-sea horizontal spatial use, the spatial grid cell method was used because it is transparent and generates more precise utilization distributions (UD), which was appropriate for this study given its small spatial scale and the increased transmission rate and spatial accuracy of GPS data (Kie et al. 2010, Maxwell et al. 2011). Grid cell size and positioning, however, can greatly affect the output (Kenward 1987). A grid cell size of $2 \mathrm{~km}^{2}$ was used because it was small enough to examine fine-scale movements but large enough to minimize gaps between used cells (Maxwell et al. 2011). The grid was centered on NIH and positioned to minimize the number of cells containing land.

UD were generated for each group following Maxwell et al. (2011). For each individual, the number of interpolated locations per grid cell was normalized to proportions using total number of interpolated at-sea locations, excluding locations $\leq 100 \mathrm{~m}$ of NIH shoreline and from post-weaning fast. These proportions were averaged cell-by-cell for all seals in each group and converted to cumulative proportions of locations per cell (cells with same proportions were summed together) to create group UD with $10 \%$ isopleths. Group home ranges (HR) were defined by the $95 \%$ UD isopleth. Each HR was divided into core and peripheral areas using the $10 \%$ UD increment at which seal space use deviated the most from random use (Bingham \& Noon 1997, Powell 2000). Core and HR areas and percentage overlap among groups were calculated (Robson et al. 2004).

To compare foraging excursions among seal groups (excludes post-weaning fast), trip distances, relative search index (RSI), duration, circular directional bearing, and circular distance were determined (Call et al. 2008). Maximum trip distance was calculated as the great-circle path (GCP) from the center of $\mathrm{NIH}$ $\left(23.06^{\circ} \mathrm{N}, 161.92^{\circ} \mathrm{W}\right)$ to the farthest GPS location for each trip. Total trip distance was the sum of straightline distances between consecutive locations for each trip, and RSI was total trip distance divided by maximum trip distance. Circular directional bearing was calculated along the maximum trip distance, and group mean circular direction was calculated using second-order analyses although number of trips among individuals was unequal (Zar 1999). The associated circular distance was used to investigate if mean trip directions were similar (range of 0 to 1 with greater values indicative of greater directional clustering of trips).

For all trip statistics, only complete trips with $\geq 2$ locations and total trip distance $\geq 2 \mathrm{~km}$ (when trip duration was $>4 \mathrm{~h}$ ) or total trip distance $\geq 4 \mathrm{~km}$ (when trip duration was $\leq 4 \mathrm{~h}$ ) were included. Locations $\leq 100 \mathrm{~m}$ of NIH were considered on-land. Mean trip statistics were calculated for each seal then averaged for each group to account for unequal number of trips among individuals. Comparisons were conducted separately for (1) weanling seal groups and (2) adult and weanling seals. Differences in maximum trip distance and RSI were tested using 2-sample independent $t$-tests or, when the assumption of equal variance was rejected, randomization tests (10000 iterations). Effect sizes $(T)$ for $t$-tests were calculated (Cooper et al. 2009). Rayleigh's test was used to test individual circular uniformity of directional bearing.

\section{Habitat use data collection and analyses}

To characterize benthic habitat, focal camera drops were conducted at 45 sites on the terraces around $\mathrm{NIH}$ and at the bank $9 \mathrm{~km}$ to the west of NIH (WNB) using an underwater video camera (SplashCam Deep Blue Pro, Ocean Systems). Site locations were randomly determined and stratified based on seal 
diving activity $(<40,40-60,60-80$, and $80-100 \mathrm{~m})$ and spatial use (unused and more and less intensely used areas). Camera drops were conducted on $5 \mathrm{~d}$ in 2010 and 2011 with the vessel platform drifting for 1 to $5 \mathrm{~min}$ (camera oriented straight down $\geq 1 \mathrm{~m}$ off seafloor; Table S2). These drift data were converted to point data using the start drift coordinates because of the homogeneity of habitat regardless of drift distance and camera distance from seafloor.

For each site, the physical and biological benthic habitat was characterized using a modified version of the NWHI classification scheme (NOAA 2003). Here, induration, or the degree of surface hardness, was defined as hard-bottom (HB) or unconsolidated (UN) sediment with additional characterization of the benthic habitat at NIH described elsewhere (Norris 2013). Proportion of sites characterized as UN or HB within the core area of each seal group was determined. To assess if these 2 habitat types were used more or less than expected by each group, percentage error was calculated for observed proportions relative to expected values for all sites (RA seals) or sites on the NIH terrace only (weanling seals).

\section{First-year survival data collection and analyses}

First-year survival of TW seals was compared with 2 control groups: (1) non-translocated weanling seals that remained at FFS (FFS controls; $\mathrm{n}=36$ ), and (2) all weanling seals, including the 8 RW seals, born at NIH (NIH controls; $n=16$ ) in 2008 and 2009. The percentage of seals re-sighted at Age 1, or in subsequent years (up to 2011), relative to total number of seals in each group was calculated as minimum first-year survival. Minimum survival was used because efforts to re-sight translocated and NIH-control seals occurred on only 12 d in 2009 to 2011 due to logistical constraints (an inability to camp on NIH limited surveys to biannual trips lasting $\leq 4 \mathrm{~d}$ with overnight stays aboard a ship). Thus, the survey effort at NIH was $<1.0 \%$ of the survey effort at FFS and insufficient to obtain reliable estimates of survival.

Because size at weaning affects first-year survival (Craig \& Ragen 1999, Baker 2008), difference in body size among treatment groups was examined using a 1 -factor multivariate analysis of variance (MANOVA). Axillary girth (AG) and dorsal standard length (DSL), collected as soon after weaning as possible, were used $( \pm 0.5 \mathrm{~cm})$. One FFS-control AG $(71 \mathrm{~cm})$ was a univariate outlier, but this individual was measured within 2 wk of weaning (Johanos \& Baker 2011) and retained in the analysis. If a difference in body size was detected, discriminant analysis was conducted to determine the relative importance of AG and DSL.

To determine whether weanling seals translocated to NIH had greater probabilities of survival than nontranslocated seals of the same cohorts, a logistic regression was used with survival to Age 1 as the binary response variable. Because AG and DSL were correlated $(r=0.833, p<0.001)$ and sex affects juvenile survival at FFS (Baker \& Thompson 2007), only AG, sex, and group were included in the model as predictors. Model selection was based on Akaike information criterion corrected for small sample sizes $\left(\mathrm{AIC}_{\mathrm{C} i}\right.$ Burnham \& Anderson 2002). Because the smallest weanling seals were not considered translocation candidates, separate MANOVA and logistic regression analyses were conducted using these same methodologies but with only weanling seals with AGs greater than the AG for the smallest seal to survive to Age 1 included.

\section{RESULTS}

\section{Health status}

Based on hematology, serum chemistry, and physical examination, seals were clinically healthy at time of handling and translocation. Few infectious agents, or antibodies to them, were detected in resident and translocated seals (Tables S3 \& S4 in the Supplement). Chlamydophila abortus antibodies, however, were detected in $42 \%$ of translocated and $77 \%$ of resident seals (titers $\leq 1: 40$ ), and several species or genera of enteric bacteria were cultured from seals in both groups. In addition, there was a difference in pathogen, or pathogen antibody, prevalence between resident and translocated seals (likelihood ratio $_{4}=$ $11.199, \mathrm{p}=0.024)$. With removal of the other enteric bacteria category, there was no difference in prevalence between groups (likelihood ratio $_{3}=5.068, \mathrm{p}=$ 0.196). Therefore, the difference likely resulted from greater prevalence of other enteric bacteria, primarily Vibrio spp., in resident seals (likelihood ratio $_{1}=$ 6.131, $\mathrm{p}=0.013)$.

\section{Foraging behavior and habitat use}

Weanling seals were translocated to NIH at an average age of $78 \pm 5 \mathrm{~d}$, and post-weaning fast duration for TW seals was $84 \pm 5 \mathrm{~d}$. Seals included in these analyses were tracked for $133 \pm 15 \mathrm{~d}$, excluding the 
post-weaning fast, with lesser tracking durations for RA seals $(98 \pm 25$ d) than for weanling seals (TW: $163 \pm 22$ d, RW: $134 \pm 29$ d; Table S1).

\section{Diving behavior}

During the post-weaning fast, TW and RW seals had similar shallow, short duration diving (Fig. 1) with almost all their time spent at depths $<10 \mathrm{~m}$ (TW: $88.2 \pm 2.7 \%$, RW: $95.6 \pm 1.0 \%$ of TAD). In contrast, after the post-weaning fast, weanling seals spent approximately $45 \%$ of TAD below $10 \mathrm{~m}$, similar to RA seals.

Dive depth patterns for TW and RW seals also were similar after the fasting period, with weanling seals most frequently diving to 40 to $60 \mathrm{~m}$ (TW: $58.0 \pm$ $6.1 \%$, RW: $51.0 \pm 9.4 \%$ of dives; Fig. 2a). Diving activity among RA seals was more variable, and dives for this group were more broadly distributed across depth bins. Dives to depths $>80 \mathrm{~m}$ were infrequent $(3.8 \pm 2.2 \%$ of dives), with the exception of 1 adult female seal that consistently demonstrated deeper diving activity ( $44 \%$ of dives $>80 \mathrm{~m}$ ). No seals dove to depths $>300 \mathrm{~m}$.

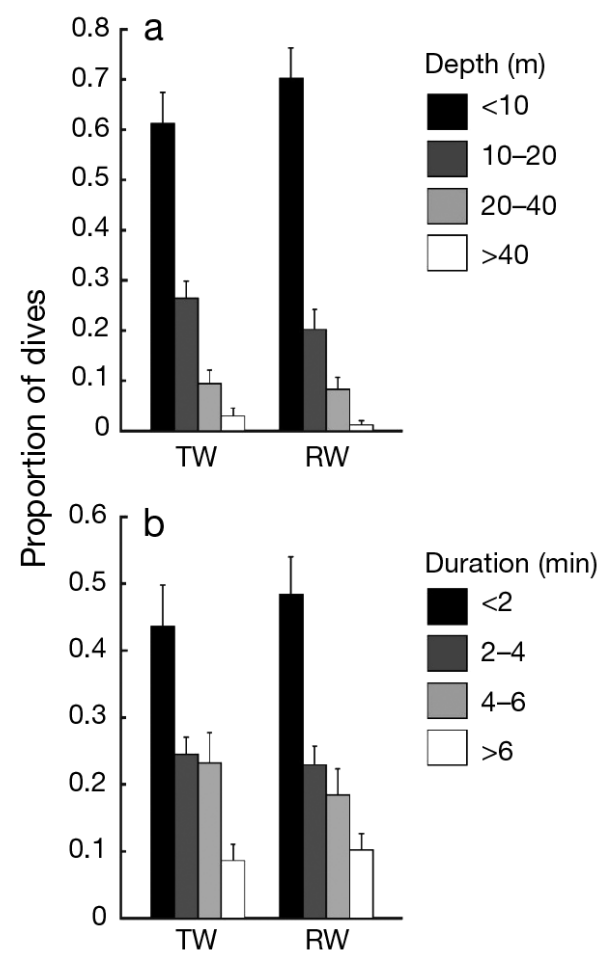

Fig. 1. Mean \pm SE proportion of dives to each (a) depth and (b) duration bin during the post-weaning fast. TW: translocated weanling $(\mathrm{n}=10)$; RW: resident weanling $(\mathrm{n}=8)$
In contrast to group trends for dive depth following the post-weaning fast, dive duration frequency histograms were more similar between RW and RA seals than weanling seal groups (Fig. 2b). Specifically, TW seals more frequently dove for durations $\leq 6 \mathrm{~min}$ $(56.3 \pm 6.0 \%$ of dives) compared to RW $(39.5 \pm 1.6 \%$ of dives) and RA $(42.4 \pm 4.5 \%$ of dives $)$ seals. For weanling seals, mean proportion of dives $\leq 6$ min was negatively related to mass $\left(F_{1,13}=18.349, \mathrm{p}=0.001\right.$, $\mathrm{r}^{2}=0.625$; Fig. S1) with 5 smaller TW seals diving for lesser durations and 3 larger TW seals diving more similarly to resident seals. Additionally, although individual seals in each group dove in excess of $25 \mathrm{~min}$, the majority of dives for all seals were $<10$ min $(95.0$ $\pm 1.2 \%)$.

\section{Horizontal spatial use}

Translocated and resident seals almost exclusively used terrace habitat around NIH and at several submerged banks (water depths $<200$ m; Fig. 3). Only 3 TW seals briefly visited the WNB terrace, and no RW seals used this nearby bank. The areas immediately around NIH and $<13 \mathrm{~km}$ east of NIH were used

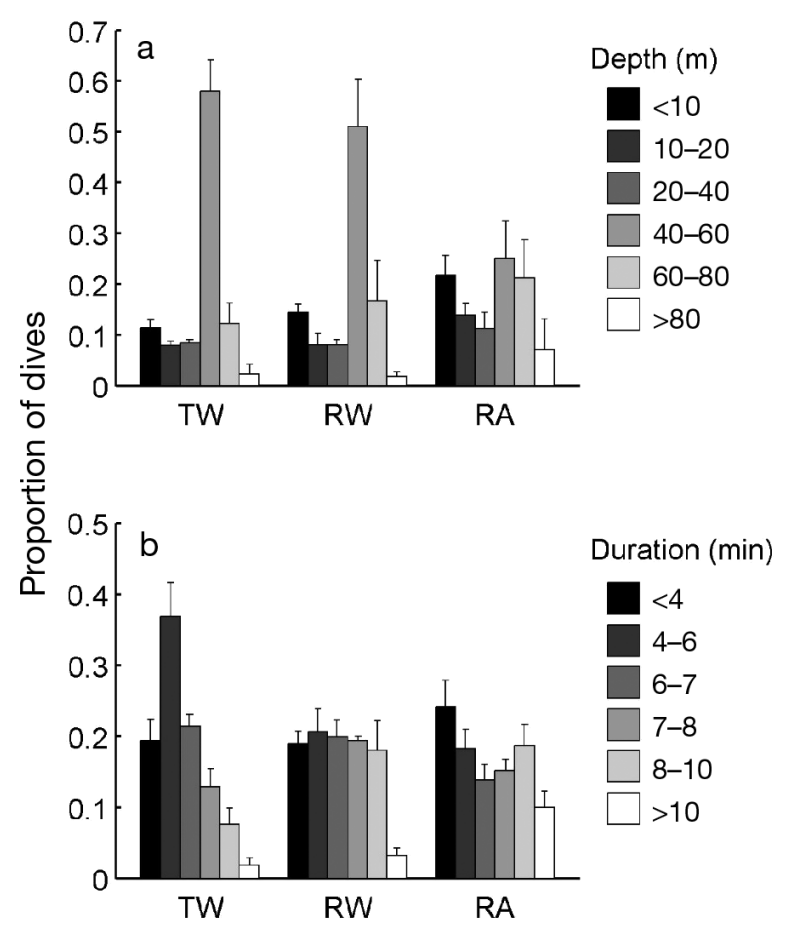

Fig. 2. Mean \pm SE proportion of dives to each (a) depth and (b) duration bin following the post-weaning fast for translocated weanling ( $\mathrm{TW} ; \mathrm{n}=8)$ and resident weanling $(\mathrm{RW}$; $\mathrm{n}=5$ ) seals compared with resident adults ( $R A_{;} \mathrm{n}=7$ ) 
to a greater degree by weanling seals. Thus, there was substantial overlap between the core (55.8\%) and HR $(46.5 \%)$ areas of TW and RW seals. In contrast to weanling seals, significant spatial segregation and greater dispersion was observed among RA seals. Five RA seals exclusively used the NIH and WNB terraces, and 2 RA seals, one of which was the adult female with deeper diving activity, foraged at 3 distant banks to the northwest and southeast of NIH. As a group, RA seals rarely used the interior region of the NIH terrace that was used by TW and RW seals and instead demonstrated greater use of the terrace edges around the $60 \mathrm{~m}$ depth contour. Consequently, only $19.6 \%$ overlap in core and $34.5 \%$ overlap in HR areas were observed between weanling and adult seal groups. Weanling and adult seals, however, had similar individual core and HR area sizes despite the RA seals' use of more distant foraging grounds because RA seals visited the same areas repeatedly.
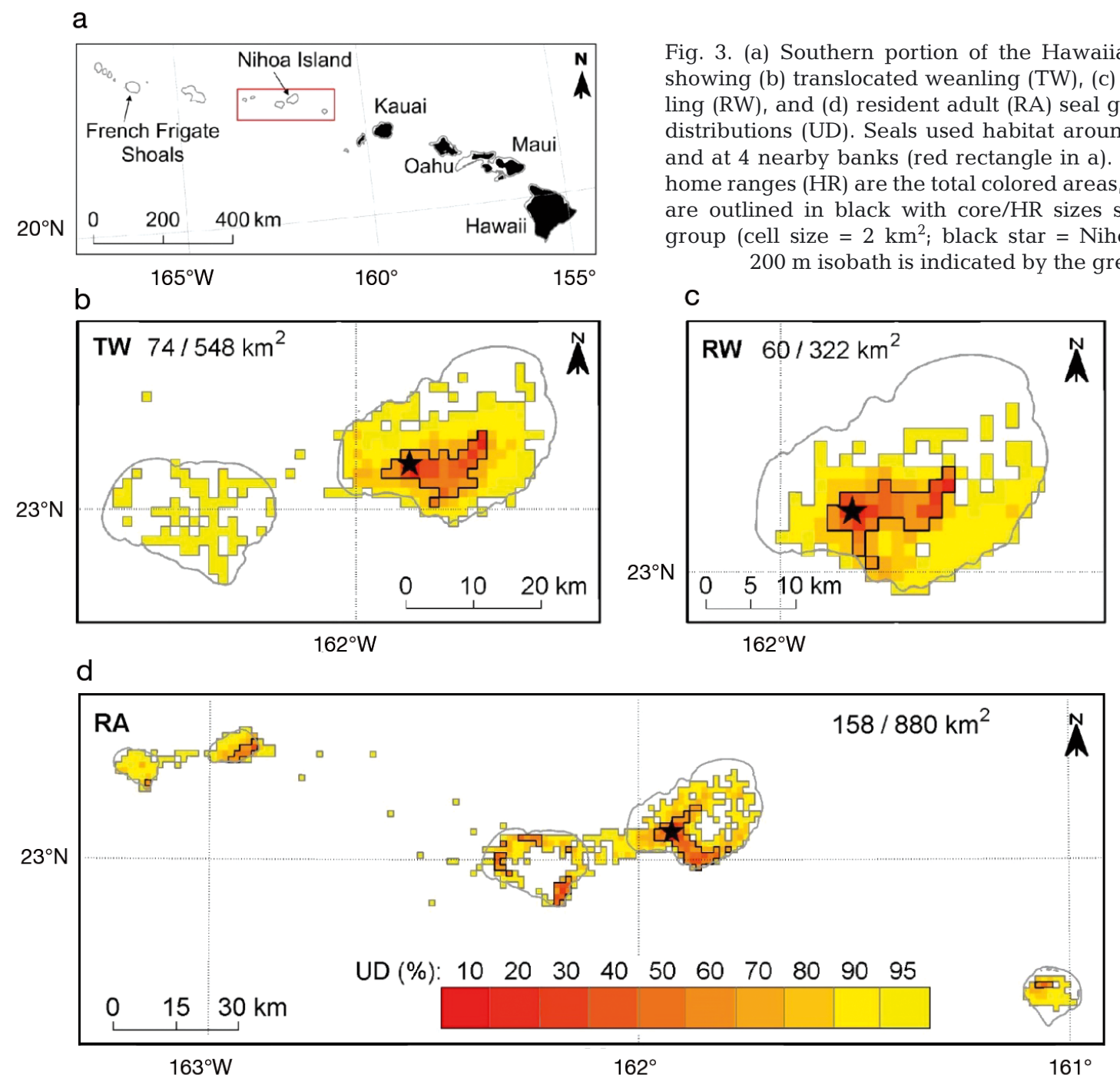
$200 \mathrm{~m}$ isobath is indicated by the grey lines

\section{C}

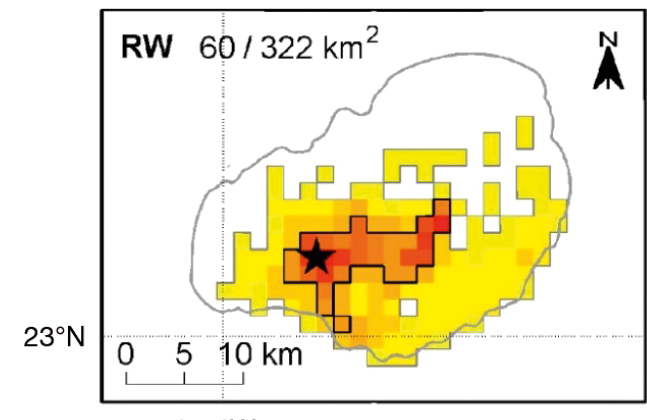

There also were similar foraging trip distances, RSIs, durations, circular directions, and circular distances among weanling seals (Figs. 4 \& S2). Thus, no differences in mean maximum trip distance $\left(t_{11}=\right.$ 1.039, $\mathrm{p}=0.321, T=0.299)$ or RSI $\left(t_{11}=-0.245, \mathrm{p}=\right.$ $0.811, T=0.074$ ) were detected between TW and RW seals. Among RA seals, however, there was greater variability in foraging trip statistics. Variance for maximum trip distance was significantly greater for RA seals compared with weanling seals $\left(F_{6,12}=263.811\right.$, $\mathrm{p}<0.001$ ), and there was a significant difference in maximum trip distance between weanling (10.0 \pm $0.5 \mathrm{~km})$ and RA $(26.3 \pm 10.9 \mathrm{~km})$ seals (randomization test, $\mathrm{p}<0.05)$. Weanling seals had greater mean RSI than RA seals; however, this result was not statistically significant $\left(t_{18}=1.128, \mathrm{p}=0.274, T=0.257\right)$. Foraging trips for weaning seals were concentrated east of NIH, whereas there was little directional clustering of foraging trips among RA seals (Fig. 4). All seals had simi-

Fig. 3. (a) Southern portion of the Hawaiian Archipelago showing (b) translocated weanling (TW), (c) resident weanling (RW), and (d) resident adult (RA) seal group utilization distributions (UD). Seals used habitat around Nihoa Island and at 4 nearby banks (red rectangle in a). In (b-d), group home ranges (HR) are the total colored areas, and core areas are outlined in black with core/HR sizes shown for each group (cell size $=2 \mathrm{~km}^{2}$; black star $=$ Nihoa Island). The 

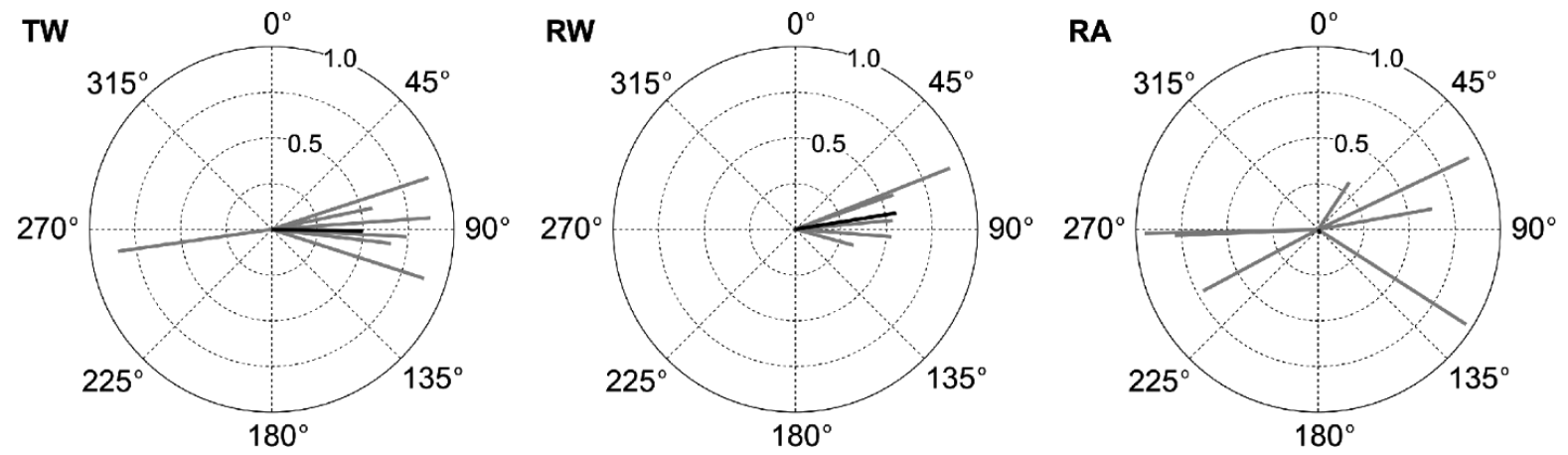

Fig. 4. Mean foraging trip circular directional bearings and circular distances (radial coordinates) for each individual (grey lines) and group (black lines). Greater circular distances were associated with greater directional clustering. TW: translocated weanling; RW: resident weanling; RA: resident adult

lar directional bearings on repeated foraging trips, except for 1 RW seal that demonstrated circular uniformity in trip direction $(z=1.960, p=0.141)$.

Habitat use

Approximately $75 \%$ of sites surveyed at NIH were HB (Table 1, Fig. S3). Pavement (solid carbonate rock) was the dominant HB type. It was, however, difficult to determine if rocky features at some $\mathrm{HB}$ sites were attached outcrops or loose rocks and dead coral fragments (i.e. talus), especially for sites on the southeastern edge of the WNB terrace. Conversely, 11 sites had UN sandy sediment $(24 \%)$, most of which were approximately $55 \mathrm{~m}$ deep and concentrated $<12 \mathrm{~km}$ east of NIH within the core areas of TW and RW seals. Thus, TW and RW seals used UN sites to a greater degree than expected relative to all

Table 1. Proportion of habitat assessment sites within the core areas of translocated weanling (TW), resident weanling (RW), and resident adult (RA) seals categorized as unconsolidated (UN) or hard-bottom (HB) sediment. Observed (Obs.) values for TW and RW seals were compared with proportion of each habitat type for sites on the Nihoa terrace only (NIH) and for RA seals for all sites combined (All) using percentage error: $\% \mathrm{E}=\left(\right.$ proportion $_{\mathrm{obs}}-$ proportion $\left._{\text {sites }}\right) /$ proportion $\left._{\text {sites }}\right) \times$ 100. Positive values for $\% E$ represent increased use by seal groups relative to proportions for surveyed sites (expected values), whereas negative \%E values represent decreased relative use

\begin{tabular}{|lcccccccc|}
\hline & \multirow{2}{*}{ NIH } & TW & \multicolumn{2}{c|}{ RW } & All & \multicolumn{2}{c|}{ RA } \\
& sites & Obs. $\%$ E & Obs. $\%$ E & sites & Obs. & $\%$ E \\
\hline UN & 0.29 & 0.45 & +59 & 0.55 & +91 & 0.24 & 0.18 & -26 \\
HB & 0.71 & 0.55 & -24 & 0.45 & -36 & 0.76 & 0.82 & +8 \\
Total no. & 28 & 11 & & 11 & & 45 & 22 & \\
\hline
\end{tabular}

$\mathrm{NIH}$ terrace sites. This relationship was greater for RW (91\% increase) than TW (59\% increase) seals. In contrast to weanling seals, RA seals used UN sites to a lesser extent relative to the proportion of UN sites for all sites surveyed ( $26 \%$ decrease).

\section{Re-sights and minimum first-year survival}

From 2009 to 2011, 18 translocated and resident seals were re-sighted in good to excellent body condition (Table S1). Most of these individuals and 3 additional RA seals also were re-sighted between 2012 and 2015, and all but 1 translocated and 2 resident seals remained at NIH. Two TW seals, however, likely died immediately after being translocated (satellite tags stopped transmitting $\leq 6 \mathrm{~d}$ post-release, seals were never re-sighted, and 1 seal did not appear to go ashore at $\mathrm{NIH}$ ). Including these 2 immediate mortalities, at least $50 \%$ of TW seals survived to Age 1. This was greater than the first-year survival of non-translocated weanling seals at FFS (31\%) but was slightly less than that of non-translocated weanling seals at $\mathrm{NIH}(69 \%)$.

There were differences in weaning body size among TW, FFS-control, and NIH-control seals (Wilk's lambda $=0.825, F_{4,118}=2.976, \mathrm{p}=0.022$ ). The first discriminant function explained $99.3 \%$ of the variance (canonical $r^{2}=0.173, \chi^{2}{ }_{4}=11.436, p=0.022$ ) and indicated that TW and NIH-control seals were similar in size $\left(\mathrm{AG}_{\mathrm{TW}}=109.9 \pm 1.9 \mathrm{~cm}, \mathrm{AG}_{\mathrm{NIH} \text {-control }}=\right.$ $108.8 \pm 3.1 \mathrm{~cm}_{i} \mathrm{DSL}_{\mathrm{TW}}=130.0 \pm 1.9 \mathrm{~cm}, \mathrm{DSL}_{\mathrm{NIH} \text {-control }}=$ $127.7 \pm 1.7 \mathrm{~cm}$ ) and larger than FFS-control seals $(\mathrm{AG}=101.6 \pm 1.9 \mathrm{~cm}, \mathrm{DSL}=122.1 \pm 1.4 \mathrm{~cm})$. Length (loading $=0.995$ ) had greater relative importance on this size difference than girth (loading $=0.747$ ).

Axillary girth was the only term retained in the most parsimonious model predicting minimum 
Table 2. Generalized linear model results comparing minimum first-year survival of 3 weanling seal groups (translocated seals and non-translocated seals from the donor and recipient sites). Change in Akaike information criterion for small sample sizes $\left(\Delta \mathrm{AIC}_{\mathrm{C}}\right)$ is relative to the best fitting model (least $\mathrm{AIC}_{\mathrm{C}}$ ). The null model includes only the intercept term. AG: axillary girth; df: degrees of freedom

\begin{tabular}{|lrrr|}
\hline & $\mathrm{AIC}_{\mathrm{C}}$ & $\Delta \mathrm{AIC}_{\mathrm{C}}$ & $\mathrm{df}$ \\
\hline $\mathrm{AG}$ & 71.833 & & 57 \\
AG + group & 73.535 & 1.702 & 55 \\
AG + group + (AG $\times$ group) & 74.725 & 2.892 & 53 \\
AG + group + sex & 75.878 & 4.045 & 54 \\
Null model & 88.398 & 16.565 & 58 \\
\hline
\end{tabular}

first-year survivorship (Table 2). Weanling seals with greater AG had greater probabilities of survival (odds ratio $=1.141,95 \%$ confidence interval $=1.057$ to 1.231 ).

To account for any size bias of selecting TW seals by including only weanling seals with $A G \geq 97 \mathrm{~cm}$ (AG of smallest surviving seal) in these analyses, minimum first-year survival was greater for NIH controls $(79 \%, \mathrm{n}=14)$ than TW $(50 \%, \mathrm{n}=12)$ and FFScontrol $(40 \%, \mathrm{n}=25)$ seals. There were, however, no differences in body size among the 3 groups (Wilk's lambda $=0.843, F_{4,94}=2.094, p=0.088$ ). For this subset of weanling seals with $A G \geq 97 \mathrm{~cm}$, again, only AG was retained in the most parsimonious minimum first-year survivorship model (Table S5).

\section{DISCUSSION}

\section{Health status}

Translocations have the potential of exposing resident and translocated individuals to novel pathogens, and individual health can affect post-release success (Viggers et al. 1993, Deem et al. 2001). This study included pre-release health assessments for all translocated seals, which are uncommon in translocation studies (Mathews et al. 2006). It was not possible, however, to perform real-time infectious disease screening on translocated or resident seals before translocations due to the remoteness of the NWHI. Instead, the potential disease exposure risk was deemed minimal because clinical signs of disease were not observed in monk seals at the donor or release sites prior to translocations and few infectious agents or antibodies have been detected in monk seals across the Hawaiian Archipelago (Aguirre et al. 2007, Littnan et al. 2007). An exception to this is that, similar to this study, Chlamydophila abortus antibodies have been found in 36 to $70 \%$ of monk seals at most NWHI sites (Aguirre et al. 2007). Although C. abortus has been linked to reproductive failure in other mammals (Brown et al. 1987, Papp et al. 1993), this pathogen has not been detected or associated with clinical disease in monk seals, despite this high antibody prevalence (NMFS unpubl. data). Thus, it seems unlikely that the low antibody titers for C. abortus detected in many resident and translocated seals affected translocation success. Similarly, most enteric bacteria cultured from seals in this study, some of which are potentially pathogenic (Thornton et al. 1998, Xie et al. 2005), were present in monk seals at other sites (Aguirre 1998, 2000, Littnan et al. 2007). Vibrio spp. was detected only in resident individuals (54\%) and likely accounted for the difference in pathogen prevalence between resident and translocated seals. Because a relatively small number of individuals were tested in this study, possible site-specific differences in exposure to enteric bacteria, especially Vibrios, as well as the potential impacts of these pathogens on monk seal health and translocations, remain unclear and require further investigation.

\section{Foraging behavior and habitat use}

Habitat quality at the release site may be one of the most influential factors affecting translocation outcome but often is only subjectively evaluated rather than being quantitatively assessed as was done in this study (Wolf et al. 1996, 1998, Armstrong \& Seddon 2008, Moorhouse et al. 2009). Deep sand fields (50 to $100 \mathrm{~m}$ ) have been identified as important foraging habitat for adult and especially yearling monk seals at FFS (Parrish et al. 2000, 2005). Similarly, weanling seals at NIH, both those resident and translocated to this site, preferentially used areas with unconsolidated sediment. Monk seals at other NWHI sites have secondary dive modes to deeper depths and may forage $>100 \mathrm{~m}$ to minimize competition with large predatory fishes (Parrish et al. 2002, 2008, Stewart et al. 2006). In contrast, resident and translocated seals at NIH infrequently dove $>80 \mathrm{~m}$, with the exception of 1 adult female that repeatedly foraged at 2 distant banks. At NIH, the sandy habitat is relatively shallow $(\sim 55 \mathrm{~m})$, and lesser apex predator biomass exists relative to most other NWHI (Friedlander \& DeMartini 2002). These factors indicate that monk seals at NIH may not be required to 
dive as deep to find adequate food resources and do so with fewer competitors. This may be particularly advantageous for young seals that have less foraging experience and reduced diving capabilities compared with older individuals. Young seals, therefore, may have improved probabilities of survival at NWHI sites that have more accessible sand fields relative to the number of seals and other predators using this habitat. However, more systematic and ongoing in situ and remote sensing surveys are needed to better characterize monk seal habitat quality throughout the Hawaiian Archipelago and identify release locations that may support successful translocations in the future.

Even with favorable habitat quality at the release site, the ability of translocated individuals to develop effective foraging strategies post-release also can greatly impact success, but this factor rarely is evaluated in translocation studies. Weanling seals resident and translocated to NIH had similar diving activities and movement patterns, both during the post-weaning fast (i.e. immediately following translocation) and after transitioning to foraging behavior that was more similar to that of RA seals. The only significant difference between these 2 groups was that TW seals more frequently dove for durations $\leq 6$ min compared with RW seals, which likely resulted from the lesser dive durations of 5 smaller TW seals. Although there were no differences in size at weaning between TW and NIH-control groups, these 5 TW seals were $15 \mathrm{~kg}$ less in mass and $9 \mathrm{~cm}$ less in girth than other TW and RW seals included in the foraging behavior analyses. Because TW and RW seals dove to similar depths, the lesser dive durations for the 5 smaller TW seals indicated these individuals had less time at the bottom to search for and capture prey. Smaller weanling seals can modify their diving behavior to compensate for constraints in dive duration and can have greater foraging success than larger individuals when prey resources are non-limiting (Burns 1999, Irvine et al. 2000), as was suspected to be the case in this study. The foraging success of the smaller TW seals, therefore, may not have been adversely affected by more frequent diving for lesser durations, especially because these individuals appeared to have similar or greater first-year survival $(60 \%)$ relative to other TW and RW seals.

In contrast to weanling seals, RA seals demonstrated greater fidelity to more distant foraging grounds, perhaps because these areas provided reliable higher-quality prey resources and/or less competition (McConnell et al. 1992, Parrish et al. 2000, 2002). There also was significant individual variabil- ity in diving activity and increased spatial segregation among adults. Thus, there were a range of foraging patterns used by seals at NIH. TW seals, however, exhibited the same narrow range of behaviors observed in similarly aged resident seals. Data from this and previous studies (NMFS unpubl. data) indicate that during the post-weaning fast, monk seals primarily remain in shallow nearshore habitats, and nursing mother-pup pairs remain in the vicinity of the birth location. Therefore, because the postweaning fast for TW seals lasted $>12 \mathrm{~d}$ post-translocation, these seals likely first moved into deeper habitats associated with foraging at $\mathrm{NIH}$, similar to RW seals. This indicated that TW seals had normal foraging activity that was not altered by translocation. The variable foraging behavior and habitat use of RA seals also indicated that substantial monk seal foraging habitat exists at NIH that young seals should be able to exploit as they grow in size. Consequently, weanling seals, resident and translocated to $\mathrm{NIH}$, should continue to thrive at this site, in part because of favorable habitat quality, and survival to reproductive age is essential for a translocation program to have a greater impact on population recovery.

\section{First-year survival}

Translocated individuals often have reduced survivorship compared with individuals resident to the release site, particularly immediately following release (Ruth et al. 1998, Reinert \& Rupert 1999). In this study, 2 TW seals likely died within 1 wk of being translocated and may have accounted for the difference in first-year survival that was observed between translocated and non-translocated weanlings at NIH ( $60 \%$ for both groups if these 2 TW seals were excluded). Because one of these seals did not appear to go ashore at NIH, a precautionary approach for future monk seal translocations that may reduce immediate post-release mortality would be to release translocated seals directly onto land, rather than a nearshore waterbased release as was necessary in this study.

Another factor that can impact post-release success is the pre-release body condition of translocated individuals, but again, many translocation studies fail to examine this relationship (Pinter-Wollman et al. 2009). Greater weaning body size has been associated with increased survivorship in monk seals, including those that were translocated (Craig \& Ragen 1999, Baker 2008, Baker et al. 2011). Similarly, translocated and non-translocated weanling seals at NIH were larger and had greater survivorship than non- 
translocated weanling seals that remained at FFS. With these differences in body size among groups, combined with the small sample sizes and minimal re-sight efforts at NIH, it was not possible to definitively determine if first-year survivorship increased as a result of translocation in this study. Previous monk seal translocations aimed at improving foraging conditions for weanling seals resulted in greater differences in survival to reproductive age for translocated $(40 \%)$ and non-translocated seals at the donor site ( $7 \%$; Baker et al. 2011). Thus, it is important that survival to reproductive age and any breeding contribution of translocated seals be determined through ongoing population monitoring efforts to better assess translocation program success.

\section{CONCLUSIONS}

Traditionally, many definitions of translocation success use long-term metrics of population stability or growth (Griffith et al. 1989, Fischer \& Lindenmayer 2000, Gusset et al. 2009). These population-level trends depend on numerous factors, some of which were examined as part of this study. There was little evidence of infectious diseases in translocated and resident seals at NIH, suggesting the risk of exposing seals to novel pathogens as a result of translocation likely was minimal. However, because exposure to novel pathogens poses a significant threat to the population recovery of Hawaiian monk seals and other endangered species (Daszak et al. 2000), pre-release health assessments that include infectious disease testing are an increasingly important component of any translocation program. When pre-release pathogen testing is not possible, which often may be the case for translocations in remote field settings, ongoing surveillance and robust risk assessment for infectious diseases may be a suitable alternative. Additionally, weanling monk seals translocated to NIH demonstrated normal, effective independent foraging with no observable post-translocation effects on movement patterns, diving activity, and habitat use. Because TW seals were still in their post-weaning fast at the time of translocation, their foraging behavior and habitat use largely developed at NIH, similar to RW seals. This indicates that individuals that are translocated with limited foraging experience are capable of rapidly adapting to their post-release environment. Although the effect of translocation on first-year survival could not be determined because of several confounding factors, translocated seals may have greater survivorship relative to non- translocated seals at FFS over a longer timeframe, likely in part because of improved foraging conditions at NIH that should support the continued survival of TW seals to reproductive age. Because numerous factors can affect long-term survival and reproduction contribution, the integrated approach used to assess translocation success in this study provides greater insight into the efficacy of this conservation strategy and further suggests that translocation aimed at mitigating prey limitation for weanling seals is a viable and important conservation tool for Hawaiian monk seals.

Acknowledgements. Funding for this study was provided by National Marine Fisheries Service and The Marine Mammal Center. We thank the many field researchers and the officers and crews of the NOAA Ship 'Oscar Elton Sette' and M/V 'Searcher' who were critical to the translocation, seal capture, and habitat assessment efforts and who provided additional project support, especially B. Braun, C. Yoshinaga, S. Guerin, M. Sullivan, S. Farry, J. Jones, L. Kashinsky, and T. Johanos-Kam. This project was conducted under Marine Mammal Protection Act Research and Enhancement Permit 10137. All activities were permitted by the Papahanaumokuakea Marine National Monument Management Board (PMNM-2008-016, PMNM-2009-001, PMNM-2010030, and PMNM-2011-001), and activities involving monk seals were approved by the San José State University Institutional Animal Care and Use Committee Protocol 917.

\section{LITERATURE CITED}

Aguirre A (1998) Hawaiian monk seal health assessment and disease status studies: a progress report. US Department of Commerce, NOAA Admin Rep, NOAA-SWFSCH-98-10, Honolulu, HI

Aguirre A (2000) Health assessment and disease status studies of the Hawaiian monk seal (Monachus schauinslandi). US Department of Commerce, NOAA Admin Rep, NOAA-SWFSC-H-00-01, Honolulu, HI

Aguirre AA, Keefe TJ, Reif JS, Kashinsky L and others (2007) Infectious disease monitoring of the endangered Hawaiian monk seal. J Wildl Dis 43:229-241

Antonelis GA, Baker JD, Johanos TC, Braun RC, Harting AL (2006) Hawaiian monk seal (Monachus schauinslandi): status and conservation issues. Atoll Res Bull 543:75-101

Armstrong DP, Seddon PJ (2008) Directions in reintroduction biology. Trends Ecol Evol 23:20-25

Baker JD (2008) Variation in the relationship between offspring size and survival provides insight into causes of mortality in Hawaiian monk seals. Endang Species Res 5: 55-64

Baker JD, Johanos TC (2002) Effects of research handling on the endangered Hawaiian monk seal. Mar Mamm Sci 18: 500-512

*Baker JD, Johanos TC (2004) Abundance of the Hawaiian monk seal in the main Hawaiian Islands. Biol Conserv 116:103-110

* Baker JD, Thompson PM (2007) Temporal and spatial variation in age-specific survival rates of a long-lived mammal, the Hawaiian monk seal. Proc R Soc B 274:407-415 
Baker JD, Littnan CL, Johnston DW (2006) Potential effects of sea level rise on the terrestrial habitats of endangered and endemic megafauna in the Northwestern Hawaiian Islands. Endang Species Res 2:21-30

Baker JD, Becker BL, Wurth TA, Johanos TC, Littnan CL, Henderson JR (2011) Translocation as a tool for conservation of the Hawaiian monk seal. Biol Conserv 144: 2692-2701

* Baker JD, Harting AL, Littnan CL (2013) A two-stage translocation strategy for improving juvenile survival of Hawaiian monk seals. Endang Species Res 21:33-44

Baker JD, Harting AL, Johanos TC, Littnan CL (2016) Estimating Hawaiian monk seal range-wide abundance and associated uncertainty. Endang Species Res 31:317-324

Bertilsson-Friedman P (2006) Distribution and frequencies of shark-inflicted injuries to the endangered Hawaiian monk seal (Monachus schauinslandi). J Zool (Lond) 268: 361-368

Bingham BB, Noon BR (1997) Mitigation of habitat 'take': application to habitat conservation planning. Conserv Biol 11:127-139

* Brown AS, Girjes AA, Lavin MF, Timms P, Woolcock JB (1987) Chlamydial disease in koalas. Aust Vet J 64: 346-350

Bryant E (2007) 2D location accuracy statistics for Fastloc(® cores running firmware versions $2.2 \& 2.3$. Tech Rep TR01. www.wildtracker.com/results_files/Technical\%20 Report\%20TR01.pdf

Burnham KP, Anderson DR (2002) Model selection and multimodel inference: a practical information-theoretic approach, 2nd edn. Springer, Fort Collins, CO

Burns JM (1999) The development of diving behavior in juvenile Weddell seals: pushing physiological limits in order to survive. Can J Zool 77:737-747

Call KA, Ream RR, Johnson D, Sterling JT, Towell RG (2008) Foraging route tactics and site fidelity of adult female northern fur seal (Callorhinus ursinus) around the Pribilof Islands. Deep-Sea Res II 55:1883-1896

Carretta JV, Oleson EM, Baker J, Weller DW and others (2016) US Pacific marine mammal stock assessments: 2015. US Department of Commerce, NOAA Tech Memo, NOAA-TM-NMFS-SWFSC-561, La Jolla, CA

Cooper H, Hedges LV, Valentine JC (2009) The handbook of research synthesis and meta-analysis. Russell Sage Foundation, New York, NY

Craig MP, Ragen TJ (1999) Body size, survival, and decline of juvenile Hawaiian monk seals, Monachus schauinslandi. Mar Mamm Sci 15:786-809

Daszak P, Cunningham AA, Hyatt AD (2000) Emerging infectious diseases of wildlife-threats to biodiversity and human health. Science 287:443-449

Deem SL, Karesh WB, Weisman W (2001) Putting theory into practice: wildlife health in conservation. Conserv Biol 15: 1224-1233

Dodd CK Jr, Seigel RA (1991) Relocation, repatriation, and translocation of amphibians and reptiles: Are they conservation strategies that work? Herpetologica 47: 336-350

Fischer J, Lindenmayer DB (2000) An assessment of the published results of animal relocations. Biol Conserv 96: $1-11$

Freitas C, Lydersen C, Fedak MA, Kovacs KM (2008) A simple new algorithm to filter marine mammal Argos locations. Mar Mamm Sci 24:315-325

Friedlander AM, DeMartini EE (2002) Contrasts in density, size, and biomass of reef fishes between the northwestern and the main Hawaiian islands: the effects of fishing down apex predators. Mar Ecol Prog Ser 230:253-264

* Griffith B, Scott JM, Carpenter JW, Reed C (1989) Translocations as a species conservation tool: status and strategy. Science 245:477-480

*Gusset M, Jakoby O, Müller MS, Somers MJ, Slotow R, Grimm V (2009) Dogs on the catwalk: modeling reintroduction and translocation of endangered wild dogs in South Africa. Biol Conserv 142:2774-2781

* Harting AL, Johanos TC, Littnan CL (2014) Benefits derived from opportunistic survival-enhancing interventions for the Hawaiian monk seal: the silver BB paradigm. Endang Species Res 25:89-96

* Hindell MA, Lea MA, Morrice MG, MacMahon CR (2000) Metabolic limits on dive duration and swimming speed in the southern elephant seal Mirounga leonina. Physiol Biochem Zool 73:790-798

Irvine LG, Hindell MA, van den Hoff J, Burton HR (2000) The influence of body size on dive duration of underyearling southern elephant seals (Mirounga leonina). J Zool (Lond) 251:463-471

IUCN (1998) IUCN guidelines for re-introductions. IUCN, Gland

Jameson RJ, Kenyon KW, Johnson AM, Wight HM (1982) History and status of translocated sea otter populations in North America. Wildl Soc Bull 10:100-107

Johanos TC, Baker JD (2011) The Hawaiian monk seal in the Northwestern Hawaiian Islands, 2004. US Department of Commerce, NOAA Tech Memo, NOAA-TM-NMFSPIFSC-28, Honolulu, HI

* Johanos TC, Becker BL, Baker JD, Ragen TJ, Gilmartin WG, Gerrodette $\mathrm{T}$ (2010) Impacts of sex ratio reduction on male aggression in the Critically Endangered Hawaiian monk seal Monachus schauinslandi. Endang Species Res 11:123-132

Kenward R (1987) Wildlife radio tagging: equipment, field techniques and data analysis. Academic Press, London

KKie JG, Matthiopoulos J, Fieberg J, Powell RA and others (2010) The home-range concept: Are traditional estimators still relevant with modern telemetry technology? Philos Trans R Soc Lond, B 365:2221-2231

KLittnan CL, Stewart BS, Yochem PK, Braun R (2007) Survey for selected pathogens and evaluation of disease risk factors for endangered Hawaiian monk seals in the main Hawaiian Islands. EcoHealth 3:232-244

Kathews F, Moro D, Strachan R, Gelling M, Buller N (2006) Health surveillance in wildlife reintroductions. Biol Conserv 131:338-347

* Maxwell SM, Breed GA, Nickel BA, Makanga-Bahouna J and others (2011) Using satellite tracking to optimize protection of long-lived marine species: olive ridley sea turtle conservation in Central Africa. PLOS ONE 6: e19905

*McConnell BJ, Chambers C, Fedak MA (1992) Foraging ecology of southern elephant seals in relation to the bathymetry and productivity of the Southern Ocean. Antarct Sci 4:393-398

Koorhouse TP, Gelling M, Macdonald DW (2009) Effects of habitat quality upon reintroduction success in water voles: evidence from a replicated experiment. Biol Conserv 142:53-60

NOAA (2003) Atlas of the shallow-water benthic habitats of the Northwestern Hawaiian Islands. Center for Coastal Monitoring and Assessment, Silver Springs, MD 
Norris TA (2013) Foraging behavior, habitat, health, and survival of resident and translocated Hawaiian monk seals at Nihoa Island, Hawaii. MS thesis, San José State University, CA

Norris TA, Littnan CL, Gulland FM (2011) Evaluation of the captive care and post-release behavior and survival of seven juvenile female Hawaiian monk seals (Monachus schauinslandi). Aquat Mamm 37:342-353

Papp JR, Shewen PE, Gartley CJ (1993) Chlamydia psittaci infection and associated infertility in sheep. Can J Vet Res 57:185-189

* Parrish FA, Craig MP, Ragen TJ, Marshall GJ, Buhleier BM (2000) Identifying diurnal foraging habitat of endangered Hawaiian monk seals using a seal-mounted video camera. Mar Mamm Sci 16:392-412

Parrish FA, Abernathy K, Marshall GJ, Buhleier BM (2002) Hawaiian monk seals (Monachus schauinslandi) foraging in deep-water coral beds. Mar Mamm Sci 18: 244-258

Parrish FA, Marshall GJ, Littnan CL, Heithaus M and others (2005) Foraging of juvenile monk seals at French Frigate Shoals, Hawaii. Mar Mamm Sci 21:93-107

Parrish FA, Marshall GJ, Buhleier B, Antonelis GA (2008) Foraging interaction between monk seals and large predatory fish in the Northwestern Hawaiian Islands. Endang Species Res 4:299-308

* Pinter-Wollman N, Isbell LA, Hart LA (2009) Assessing translocation outcome: comparing behavioral and physiological aspects of translocated and resident African elephants (Loxodonta africana). Biol Conserv 142: 1116-1124

Powell RA (2000) Animal home ranges and territories and home range estimators. In: Boitani L, Fuller TK (eds) Research techniques in animal ecology: controversies and consequences. Columbia University Press, New York, NY, p 65-110

Reif JS, Bachand A, Aguirre AA, Borjesson DL, Kashinsky L, Braun R, Antonelis G (2004) Morphometry, hematology, and serum chemistry in the Hawaiian monk seal (Monachus schauinslandi). Mar Mamm Sci 20:851-860

Reinert HK, Rupert RR Jr (1999) Impacts of translocations on behavior and survival of timber rattlesnakes, Crotalus horridus. J Herpetol 33:45-61

Reiter J, Stinson NL, Le Boeuf BJ (1978) Northern elephant seal development: the transition from weaning to nutritional independence. Behav Ecol Sociobiol 3:337-367

Reynolds MH, Seavy NE, Vekasy MS, Klavitter JL, Laniawe LP (2008) Translocation and early post-release demography of endangered Laysan teal. Anim Conserv 11: 160-168

Robson BW, Goebel ME, Baker JD, Ream RR and others (2004) Separation of foraging habitat among breeding sites of a colonial marine predator, the northern fur seal (Callorhinus ursinus). Can J Zool 82:20-29

Editorial responsibility: Brendan Godley, University of Exeter, Cornwall Campus, UK
Ruth TK, Logan KA, Sweanor LL, Hornocker MG, Temple LJ (1998) Evaluating cougar translocations in New Mexico. J Wildl Manag 62:1264-1275

Salafsky N, Margoluis R, Redford KH, Robinson JG (2002) Improving the practice of conservation: a conceptual framework and research agenda for conservation science. Conserv Biol 16:1469-1479

Seddon PJ, Strauss WM, Innes J (2012) Animal translocations: What are they and why do we do them. In: Ewen JG, Armstrong DP, Parker KA, Seddon PJ (eds) Reintroduction biology: integrating science and management. Blackwell Publishing, Oxford, p 1-32

* Sheean VA, Manning AD, Lindenmayer DB (2012) An assessment of scientific approaches towards species relocations in Australia. Austral Ecol 37:204-215

Stewart BS, Antonelis GA, Baker JD, Yochem PK (2006) Foraging biogeography of Hawaiian monk seals in the Northwestern Hawaiian Islands. Atoll Res Bull 543: 131-145

Swan KD, McPherson JM, Seddon PJ, Moehrenschlager A (2016) Managing marine biodiversity: the rising diversity and prevalence of marine conservation translocations. Conserv Lett 9:239-251 doi:10.1111/conl.12217

Thornton SM, Nolan S, Gulland FMD (1998) Bacterial isolates from California sea lions (Zalophus californianus), harbor seals (Phoca vitulina), and northern elephant seals (Mirounga angustirostris) admitted to a rehabilitation center along the Central California Coast, 19941995. J Zoo Wildl Med 29:171-176

* Tremblay Y, Shaffer SA, Fowler SL, Kuhn CE and others (2006) Interpolation of animal tracking data in a fluid environment. J Exp Biol 209:128-140

Viggers KL, Lindenmayer DB, Spratt DM (1993) The importance of disease in reintroduction programmes. Wildl Res 20:687-698

* Watanuki Y, Burger AE (1999) Body mass and dive duration in alcids and penguins. Can J Zool 77:1838-1842

*Wolf CM, Griffith B, Reed C, Temple SA (1996) Avian and mammalian translocations: update and reanalysis of 1987 survey data. Conserv Biol 10:1142-1154

*Wolf CM, Garland T, Griffith B (1998) Predictors of avian and mammalian translocation success: reanalysis with phylogenetically independent contrasts. Biol Conserv 86: 243-255

*Worthy GA, Lavigne DM (1987) Mass loss, metabolic rate, and energy utilization by harp and gray seal pups during the postweaning fast. Physiol Zool 60:352-364

Xie ZY, Hu CQ, Chen C, Zhang LP, Ren CH (2005) Investigation of seven Vibrio virulence genes among Vibrio alginolyticus and Vibrio parahaemolyticus strains from the coastal mariculture system in Guangdong, China. Lett Appl Microbiol 41:202-207

Zar JH (1999) Biostatistical analysis, 4th edn. Prentice Hall, Upper Saddle River, NJ

Submitted: July 20, 2016; Accepted: November 9, 2016

Proofs received from author(s): January 22, 2017 